\title{
An Analysis of the Mysticism Behind Gauguin's Paintings
}

\author{
Xiaonan Zhang ${ }^{1, *}$ Bingying Wang ${ }^{1}$
}

\author{
${ }^{1}$ Arts College, Sichuan University, Chengdu, Sichuan 610207, China \\ *Corresponding author. Email: 361791265@qq.com
}

\begin{abstract}
Paul Gauguin is often regarded as the representative painter of post-impressionist paintings, but in fact Gauguin was also one of the top ten artists under the influence of symbolism in the ninth century and was also regarded as the leader of symbolism. Impressionist and neo-impressionist painters tried their best to reproduce the natural things objectively, while Gauguin, influenced by the ideological trend of symbolism, wished to transcend the superficial truth and pursue the emotional truth under the surface. The analysis of him mainly focuses on his symbolism, but Paul Gauguin pursues mysterious art all his life and also reflects the mysterious side of the art country. His paintings are filled with an ineffable spirit. Based on the expression of Gauguin's mysticism in his paintings, this paper mainly analyzes the theme of his paintings, its characteristic composition and color analysis, as well as his research on mysticism painting, and finally analyzes the mysticism color of Gauguin's paintings and the profound meaning of the mysterious color behind his paintings.
\end{abstract}

Keywords: painting, mysticism, symbol, color, distinctness

\section{INTRODUCTION}

Paul Gauguin was born in Paris in 1848 and was of mixed race. He was "a passionate lover, willing to sacrifice himself for his ideals, gentle and boring, naive and cunning, a hesitant and determined artist and swindler." Some critics have commented on Gauguin. In fact, among the post-impressionist painters, Paul Gauguin and Van Gogh focused on the expression of spirituality and endowed the picture with symbolic meanings. They also oppose the division of color, bold use of bright colors flat, and pay attention to the use of line. Gauguin's painting, with its originality and symbolic tendency, as well as the so-called "synthesis" style of painting, is unique in the western modern history, and has deeply influenced future painters. Dali, a surrealist painter, is known as surrealism. He follows Gauguin's surreal dreams with dreams, meanings, realistic and reasonable deformed objects. Gauguin's relentless pursuit of art filled his paintings with a lot of his own ideas, and also made his paintings even more mysterious. Gauguin's artistic style can be summarized as simple shape, strong sense of structure, bright color contrast, showing uniform and single flat color. Not only that, but his works are full of clear lines and the huge sense of body description, which are full of decorative meanings and mysterious religious thoughts. These are all manifestations of the mysticism in his paintings.
In the following part, the author will analyze the mysterious theme expression of Gauguin's painting from two aspects, namely the theme of Gauguin's painting and color composition.

\section{MYSTICAL RELIGION}

We can see that Gauguin's life in Brittany, Panama and Martinique brought out the most primitive wildness, the naked women and the most primitive life brought out his deepest passion for creation. As a result, most of his works show the simple life of islanders, the customs of tropical areas, the strong and handsome bodies and bright clothes of aborigines.

And in these most primitive manifestations there are hidden mysterious meanings. There were many paintings of mysterious religions in the 19th century, but Gauguin's paintings were different in many ways.

In particular, his paintings can reflect his inner mysterious religious thoughts. Gauguin's "Post-Sermon Fantasy" (or "Jacob and the Angels wrestle"), painted in the late summer of 1888, is one example ("Fig. 1"). Gauguin's painting represents a religious story from the Psalms, and he doesn't have a direct answer to why he painted it. He simply wrote to Vincent Van Gogh: "I think I have painted the simplicity of the characters and the simplicity ruled by superstition. The overall effect is very serious. To me, the scenery and the wrestling in this painting exists only in the imagination of people praying after a sermon. There is a contrast between the 
natural reality of the crowd, and the tug of war over a landscape that exists out of proportion in the imagination. "The subject, in the Middle Ages, was often referred to by painters as "Christ's struggle on earth" or "the comparison of virtue and vice as the symbol of "quantity". But Gauguin went out of his way to paint it in the natural landscape of Brittany. I think this resetting is what makes this painting unique. Indeed, it seems to be an expression of fantasy: in this painting, after hearing a sermon, a group of Brittany peasant women are presented with a biblical vision of James wrestling with an angel. But Gauguin wants to use this combination of religious legends and real life to express his own understanding of the meaning of life and the proposition he has been exploring: how to live as a person? Is "civilization" the only destination for human beings? No matter what kind of civilization people are in, there is a potential connection. Although different races have different choices for "civilization", are there resonances in belief, emotion and sense? These questions seem to me to be the ultimate concern for humanity expressed in Gauguin's paintings. Gauguin is often portrayed as a very brave, maverick artist who broke away from civilization to become a "hermit" on an island in the South Pacific. But a closer inspection reveals that this is only a superficial phenomenon. Gauguin's paintings depict the island's original style so truly and beautifully, and the candid, sincere and passionate nature of his paintings can be felt immediately by the viewer. The real source of this appeal comes from the artist's own thoughts. The theme, plot, composition and color in the picture are all derived from Gauguin's respect for life, his approval of people living in primitive life and his belief in truth.

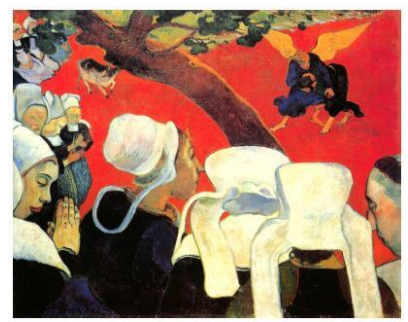

Fig. 1. Jacob wrestled with the angels.

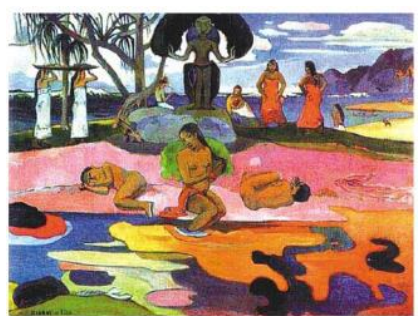

Fig. 2. Worship god day.

Although his subjects seem to be illusions, this true, persistent belief can be confirmed in the picture. The theme mystified his painting.

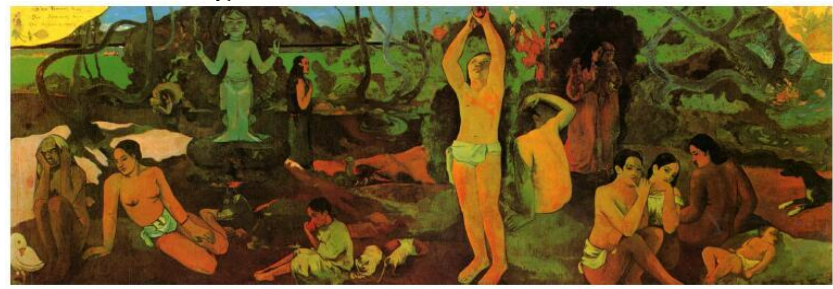

Fig. 3. Where we come from: who we are, where we are going?

The Tahiti paintings developed by Gauguin are not necessarily consistent in the exploration of modeling space. The artist's imagination is filled with many different concepts, visual and symbolic, each of which has its own form of expression best suited to its shape. Thus, the Festival of Reverence has in some ways become a traditional landscape painting, composed of a marked reduction in depth. The figure illustrates the non-Western influences that fascinate him, from ancient Egypt to modern Polynesia. That "god" is the product of the artist's imagination. Gauguin paid much attention to the mystery of the subject and the local devotion to god. Honest, but he was preoccupied with the mystery of the red, blue and yellow shapes of the curved lines. That kind of line fills the picture.

\section{UNIQUE SENSE OF PICTURE FORM}

Of course, in addition to the religious meaning of Gauguin's paintings, there is also a strong sense of mysticism: "Simple colors, bold strokes, thick tones, large areas of flat paint, no emphasis on light and shade changes and three-dimensional sense, focusing on decoration, full of symbolism. It reflects the tendency of European art to return to the primitive and pursue the expression of life origin."

In "Jacob wrestling with the angel," this picture high let viewers have an immersive feeling more, produce a kind of illusion: one like in one of those prayers, that scenario seems to occur when people concentrate on prayer, in the sight of the illusion of Jacob wrestling with the angel, and I secretly opened 
his eyes just witnessed it all. Why does this picture leave such an impression? In fact, this depends on Gauguin's planarity but powerful composition performance. Gauguin divides the picture into two parts with an oblique trunk. He placed the peasant women at the bottom of the picture; Wearing wide white hats with their backs to the audience, they stood out in black dresses.

Although Gauguin's techniques emphasized color and graphic tendencies, he exaggerated the proportions of front and rear figures to give the painting an immediate sense of perspective. In other words, he divides the picture into two layers. The first layer is the peasant women who have sex with the audience, and the audience must "stand on their toes" and look through the first layer if they want to see the fighting scenes of the gods. The second layer, at the top right, depicts the peasant women's illusion: the winged angel is entangled with Jacob. All the figures in the painting are set off against a large red background. This piece of red can represent the field or the sky. The strong colors in the painting are all non-naturalistic and are completely determined by the artist's subjective feelings. Its strong contrast fills the picture with rhythm. There are no shadows in the images. Instead of the traditional perspective techniques we are used to seeing, dark round lines are used to make the scene stand out and not drown in the intense red like the sun. Gauguin's deliberate simplification of the landscape and character contours is quite remarkable here. This simplified make all images taken individually more composition, no insight, no projection, no fine detail, but he will be the simpler form combination is very clever, the contour curve ups and downs, full of rhythm, make a harmonious picture of the dynamic, as if the fighting will continue, or will be out of the frame. So Gauguin managed to create a sense of space by combining flattened images in his images to compensate for the loss of dimensioning he intentionally sketched out the characters.

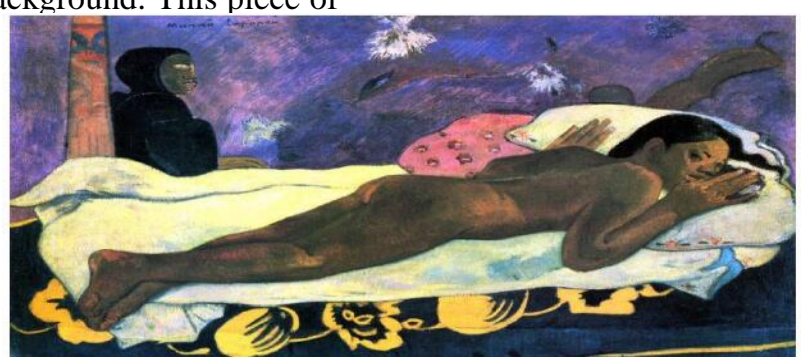

Fig. 4. Wandering souls.

His work "Worship god festival" this painting gives the impression of a mysterious dance, winding lines. All around the picture, the colors had gone beyond the limits of the outline, flooding in like countless streams. ("Fig. 2") Blue, purple, yellow and rose are alternating from bottom to top in a continuous way, which actually makes one look like a roundabout rather than a whole. The swirl is a decorative unity based on the shape of the deity. Gauguin's intention, no doubt, was to create a mystical effect on the painting, although the scenes he presented seemed dramatic.

His greatest work was "Where Do We Come from: Who Are We and Where Are We Going. This oil painting contains rich life philosophy.("Fig. 3") $\mathrm{He}$ synthesized his fantasy in his dream and his feeling of living in Tahiti into only a few simple colors: red, yellow, blue and green. However, these simple colors combined with his simple modeling structure in the picture also reflect the mysterious religious atmosphere. The baby in the painting represents the birth of human beings. The fruit picking in the middle implies that Adam picked the fruit of wisdom and thus represented the survival and development of human beings. In the back, there are several overall images of the old people, which represent the basic laws of human destiny from birth to death, and draw a trilogy of human destiny, which alludes to Gauguin's philosophical inquiry on the meaning of life, with certain religious meaning and mysterious color. The reason why these pictures of his have religious meaning is that he combined the shapes with religious thoughts with his pictures and added colors. The religious thoughts of the pictures are well reflected. In my opinion, the reason why his paintings have a mysterious religious meaning is related to the background of Tahiti and the belief in Gauguin at that time. He combined the local style religion and selfbelief to form his own unique mysterious religious thoughts.

\section{PRAYER IN THE REALM OF MYSTERY}

Two scenes often overlap in Gauguin's mind, one real, the other imaginary or artistic. "Yellow Christ," "Jacob and the Angels wrestle," are all depictions of primitive praying scenes. Why James and the Angels wrestle has an obvious religious mystique. But in fact, every piece of Gorgon's creation on the theme of the Bible has a strong mysticism color. They combine the imaginary content with the real events from different perspectives and different story forms, to maximize the expression of gorgon's theme of narration and reflect 
the prayer from the mysterious country. The oil painting "Yellow Christ", with its tile surface, strong color, bold outline and simple shape, reflects the style characteristics of Gauguin's "synthesis" painting. The whole picture is supported by the figure in the foreground, the vertical column of the cross and the horizontal bar at the top. The streaks of fields, sky and crosses contrast sharply with the undulating curves of women and trees; the flat, extended form contrasts strongly with the rounded, closed form. All images are unified in a bright and simple figure. The colors, though magnificent, showed the natural simplicity of the Scene; the figure of the woman is elegant, but the temperament of the farmer is still very clear. In the painting, the uniform color plane and lines around the image reflect Gauguin's deliberate pursuit of simplicity and simplification, which forms a sharp contrast with the impressionism style. The painting reflects the artist's careful observation of the subject: the peasant woman's dress is very precise, the light is cold and typical of Brittany, and the fields are harmonious with greens and yellows. In addition, the cross refers to a painted wooden image of the Crucifix in a church near a Bridge. Here, however, the painter has gone beyond naturalistic observation to the pursuit of emotional expression. He wrote in his diary "Impressionists are obsessed with the study of color without any freedom... They focus only on the eyes. The eye, indifferent to the mysterious core of the mind, falls into the realm of mere scientific reasoning." The expression of the "mysterious core of thought" is precisely Gauguin 's goal. Although he was not a farmer at all, he wanted to convey in his paintings the "rustic naivety and naivety" that he found in the people of Brittany. Therefore, with simplified composition, he thickened the round and corridor lines and strengthened the color concentration. His purpose was to make the picture no longer just a record made by an objective observer, but a direct visual symbol of simple and devout religious belief. And used this special color and light to reflect the prayer of the mysterious country.

Gauguin, referring to the wandering souls ("Fig. 4") this picture said to his inspiration, he nearly one day late at night to reach the door, the door, lights already out, the room was dark, he suddenly felt a fear and distress, he felt his lover tai o mana must have left him, but when Paul Gauguin lit a match, he found, the mana naked and lay stiffly in the dark, round with eyes full of fear, looks at the front like the smell the smell of death. Gauguin wanted to transform this scene into his own creation. We can take a look at this painting. The posture of the woman lying on the bed was very beautiful. Gauguin turned the sheets yellow, which he thought would create a sense of surprise in the audience. Undeniably high more color has a wide appeal, as a sudden wind will you stick to a completely new world, Gauguin patch on the image processing is very have their own unique ways, he is always very careful to handle the color relations between background and the characters, picture there is always a heavy piece to do balance, in this way to characters' golden luster. In this picture, he hopes to create illusion was lit by oil lamps, purple background of heavy colors make the picture appears dignified and terrible, and the death is hidden in large purple background, ghosts dressed in black, also a dark face, and with a white light eyes, it seems that he saw where, where is the end of life. This is what Gauguin wants to achieve. Why did Gauguin paint death through his image of horror? In the eyes of Gauguin, death is not known for living and grief, but as an artist, the theme of death is not only the reality of grief, and people into a mysterious world of death, the process of as high more this "souls" paintings high for the practical sheet of yellow here to the background of purple and orange. The human body is connected to the blue bedspread. What arose before our eyes was a sudden, luminous harmony, as if it were one of those phosphorescent glimmers which the Maori tribesmen regarded as wandering souls. Such mystical representations are characteristic of Gauguin's paintings.

\section{IMPLICATIONS FOR LIFE}

Where do we come from? What are we? Where are we going? (hereinafter referred to as "I") ("Fig. 3") the painting to the life of the two steps to develop the theme: birth, life and death. The composition of the picture has completely abandoned the classical artistic idealized schema of Celie, and is more inclined to the scattershot perspective with decorative meaning.

The elements in the picture are the author's declarative symbols, which are unfolded from right to left according to the narrative logic. To the left, from death to life. On the left side of the picture, the young girl and the dying old girl, youth. The beauty of friends and the ugliness of the fading well reveal the sorrow of old age and death. Behind them, the ancient god with his faint blue light stretched out his arms and spoke. To the right of the statue is a ghostly woman who seems to be listening. In the center, a half-naked man is at work picking fruit - Adam in the Garden of Eden, where humanity lives. In the portrayal of. "Behind him, a halfnaked woman, her back to him, is watching in amazement as two dressed women (auspicious figures)", symbolizing the destruction of the original peace and serenity. On the right side of the picture is a sleeping baby and three women sitting upright. The smile of ancient style, with the kindness of maternal love, is the portrayal of the beginning of life, full of hope and innocence. A bird protrudes from the left edge of the picture, and a dog extends into the right edge of the picture, indicating the continuation of the picture and symbolizing the cycle of life and death. The painting uses symbolism, full of mysterious 
atmosphere, is the portrayal of the author's dream. Gauguin once described his dream as: "A musical poem, rather than a plot. In A Lost Soul, Gauguin interprets his work as music and literature. Can still be found in "I" and draw the corresponding two parts: music, such as the Arab mural crisscrossed the tendrils of bedding out the background of the continuous chaotic vibration, large area deep dark blue-green tone compared with loud, bright yellow, electric blue gods pull the prelude of the mysterious fruit of red and blue stars played one after another magnificent soprano. In literature, the spread of life and death, the dialogue between the gods and the living create mysterious dramatic dreams. Gauguin, however, denies the literariness of his work in other texts, "trying to give my dreams (without the use of words) an image." He emphasized the role of color." Color, like music, is the same vibration, the most universal thing that can be achieved in nature, and therefore also the most ordinary thing. This is the inner force." Probably no painter before Gauguin had emphasized the power of color as much as he did, and by color he meant" solid color, "for which" everything must be sacrificed." Impressionist claims that "the 'right' colors are lifeless, frozen, they lie." In fact, Gauguin gave the painting something more. He didn't expect such a title at the start: "Obey the moon, I found the title later." But surely Tolstoy's 1886 book What Shall We Do? "Prompted him to use a heckling tone. Perhaps it was this philosophical inquiry that made Gauguin, after taking arsenic, give up the idea of death. The philosophy inspired by the painting made him once again curious about the future of life and dispelled his feelings of helplessness. Gauguin's influence on later generations is enormous. He was sure of this himself: "The painters who will come after me, even those who will not yet be born, owe me a debt of gratitude. The next generation of painters, when they are free, will owe the elder a greater one. "Since Gauguin, academic dogmas, romantic or realistic naturalism have been swept into history." Art becomes a subjective distortion of nature, not a copy of nature". The art of painting has never been as subjective as what they do. Gauguin's great liberal spirit has influenced generations. He wanted to be "free to paint," "free to love, free to sing, free to die." Although his ideal never came true, we can definitely smell the original free fragrance in his famous book Noa, Noa. "God is not with the scholar, he is in the poet's dream." Gauguin wrote a poem for the painting "I" as a final footnote: "Where are we going?" An old woman is going to die. A strange stupid bird made the conclusion. Who are we? The existence of uncertainty. Instinctively, one asks what all this means. Where do we come from? Source. Children. Common life. This may be Gauguin 's inspiration to life.

\section{CONCLUSION}

"Gauguin made an extremely important contribution to all modern aesthetics, and his theory of art is more imaginative than declarative. It is an anti-naturalism, reductionism, poetry and variation in painting; Pure line, original color, rejection of Greco-Latin culture and Renaissance traditions, deliberate imagination in search of images, dreamlike, subconscious, and inspiration from eastern and primitive cultures, his powerful influence in practice and theory went beyond his own creation.

"Gauguin's artistic charm was unbeatable during his bumpy career. The sight of Paul Gorgon's paintings is like a dream, like another world, like an escape. In Gauguin's painting, man returns to the original stage, the purest stage without utility or eroticism, and that is the most beautiful conception, and that is what he desires. Although he lived with the people around him, he was different. He did not see the world with his eyes, but felt it with his heart. The world in his paintings was far away from the real life, and the dream-like images seemed to come from the distant heaven and mysterious countries. It also seems that he is trying to convey some message of the mystic state to us from his pictures. From these images we can also see that his mind has long since left the real life and traveled in his fantasy world, where man was only on the wasteland, walking with wild animals as if he had returned to the primitive state. At this time, he finally understood why he could quit his well-paid job and abandon his wife and children. Because he did not belong to the real society, his thoughts belonged to God, so he could see human problems from the perspective of God. As a man, he was ahead of his time. He was supposed to be an elf sent by God to paint, or an emissary from a mysterious realm.

\section{References}

[1] Paul Gauguin. Where is the passion of life [M]. Tianjin: Baihua Literature and Art Press, 2000

[2] Francoise. Gauguin - The wild in my Heart. [M]. Translated by Su Shan, Shanghai: Shanghai Translation Publishing House, 2004.10, p. 42.

[3] Cui Qingzhong. History of modern art. [M]. Beijing: People's Fine Arts Publishing House 2004.

[4] Wang Duanting, Zhai Mo. Western Modern Art School: PostImpressionism". [M]. Beijing: People's Beauty Shu Press.

[5] Wang Xiaojun. Analysis of the formal beauty in Gauguin paintings. Journal of Kangding National Normal College 18Volume 2, April 2009.

[6] Yang Ying. Yi Hai Tuying - the 60 most creative Paintings in the West [M]. Shanghai: Shanghai People's Art Publisher, 2000

[7] The Master is modest, into the Master Gauguin, People's Fine Arts Publishing House, 2002

[8] Zong Baihua's Complete Works [M]. Hefei: Anhui Education Press, 1994.

[9] John Russell. The Meaning of Modern Art. Nanjing: Jiangsu Fine Arts Publishing House, 1996.

[10] Paul Gauguin. Where is the passion of life [M]. Tianjin: Literature and Art Press, 2000.

[11] He Qing. Modern and post-modern [M]. Hangzhou: China Academy of Fine Arts Press. 